\title{
KEJAWEN SPIRITUALISM: THE ACTUALIZATION OF MORAL VALUES AT PAGUYUBAN SUCI HATI KASAMPURNAN IN CILACAP
}

\author{
Mustolehudin and Siti Muawanah \\ Office of Religious Research and Development \\ Ministry of Religious Affairs, Indonesia \\ Email: mustolehuddin@gmail.com
}

\section{Abstract}

In Java, the existence of penghayat-believing in the One Almighty God-has grown significantly during the early reign of President Joko Widodo. This is supported by the Regulation of Ministry of Education and Culture Number 27 in 2016 about education services related to the belief in the One Almighty God at schools. Paguyupan Hati Suci Kasampurnan is one of penghayat groups in Cilacap which implements the teaching of budi pekerti (good behaviors) towards its adherents. This is a qualitative research examining the hidden meaning contained in the guidance book of Paguyupan Hati Suci Kasampurnan through semiotic analysis. This study results in two findings. First, the main source used at this paguyuban is Kitab Adam Makna. Second, the main teaching of this paguyuban is the teaching of good behaviors towards the adherents in order to reach the level of perfect life which is known as manunggaling kawula gusti.

Di Jawa, keberadaan penghayat terhadap Tuhan Yang Maha Esa mengalami perkembangan yang cukup signifikan pada awal pemerintahan Presiden Joko Widodo. Hal ini dikuatkan dengan terbitnya regulasi Menteri Pendidikan dan Kebudayaan Republik Indonesia Nomor 27 Tahun 2016 tentang layanan pendidikan kepercayaan terhadap Tuhan Yang Maha Esa pada satuan pendidikan. Paguyuban Suci Hati Kasampurnan merupakan salah satu kelompok penghayat 
di Cilacap yang ikut berperan aktif dalam mengimplementasikan ajaran budi pekerti kepada pemeluknya. Melalui pendekatan kualitatif, penelitian ini berupaya mengkaji makna yang tersirat dalam kitab ajaran Paguyupan Hati Suci Kasampurnan melalui analisis semiotika. Hasil penelitian berupa dua temuan. Pertama, sumber ajaran Paguyuban SHK adalah Kitab Adam Makna (berupa simbol-simbol yang terdapat di jagat raya). Kedua, bahwa intisari dari ajaran paguyuban ini adalah mengajarkan budi pekerti luhur sebagai dasar untuk memperoleh kesempurnaan dengan Tuhan (manunggaling kawula gusti).

Keywords: good behaviours; Kejawen; Paguyuban Suci Hati Kasampurnan.

\section{Introduction}

During the reign of President Joko Widodo, the existence of "penghayat" groups has grown rapidly not only in society but also at schools. The case of a student in SMKN 7 Semarang who did not pass the grade because he is an adherent of "penghayat" attracted public interest (Rofiudin, 2016). Such case will not happen in Cilacap because the local government of Cilacap provides the students of "penghayat" some spesific schools. According to Muslam (the teacher of "penghayat" in Cilacap) there are 14 schools in Cilacap which are specific for the students of "penghayat". Those schools are SDN (State Elementary School) Bojongsari 3, SDN Margasari 1, SDN Margasari 3, SDN Gandungmanis 3, SMPN (State Junior High School) Kedungreja 3, SMPN Cipari 1, SMPN Gandungmangu 3, SMPN 1 Jeruklegi, SMPN 1 Adipala, SMPN 2 Adipala, SMK (Vocational School) Yos Sudarso, SMAN (State Senior High School) Bantarsari, SMAN Atap, and SMAN 1 Cilacap (interview, 29 November 2016). The education for "penghayat" is under the guidance of Majelis Luhur Kepercayaan terhadap Tuhan Yang Maha Esa Indonesia (MLKI - a council for "penghayat" people).

According to MLKI, "penghayat" groups whose main teaching is the belief in the One Almighty God (attached to no religion) have been existed in Nusantara for a long period of time and have been inherited from generation to generation. Therefore, the teachings of "penghayat" groups do not contradict with the spirit of Pancasila and UUD 1945 (Hartini, 2014)

In Cilacap, there are 29 "penghayat" groups registered to MLKI. They define the term "belief in God" similarly with other groups. Here are some definitions of "belief in God" according to Paguyuban Sumarah, Sapto Dharmo, Kapribaden, Himpunan and Penghayat Kepercayaan. 
According to Sapto Dharmo, "belief in God" is a spiritual belief which requires the adherents to worship God the Almighty and live their lives based on seven sacred duties (dharma) in order to gain happiness both in the world and hereafter. The spiritual revelation of Sapto Dharmo was revealed to Hardjosapoera in 1952 in Pare Kediri (East Java) (Rosidi, 2011: 15).

The teaching of "Kapribaden" is a spiritual act (laku) which teaches the adherents to know himself before knowing God. The main goal of this doctrine is to teach the adherents to deeply know "urip" (life) and serve it because the majority of human enslave the "urip" so that the life is broken (Fauziyah, 2014: vii).

Paguyuban Suci Hati Kasampurnan (PSHK) is a "penghayat" group in Cilacap which few articles talk about. This article will discuss the sources used in this paguyuban and its main teachings.

\section{Theoretical Review}

Actually, the most important teaching of PSHK is good behavior with which the adherents can gain "kasampurnan" (the perfection of life) in order to reach higher level of manunggaling kawula gusti. Therefore, the theories applied in this article are ethics and moral.

The word ethics is derived from Greek word "ethos", which literally means disposition or the spirit of community. Bertens (2007: 6) said that ethics is a set of moral values and norms which functions as the moral guidance for certain community, while Syukur (2010: 11) stated that ethics is something related to moral theory. Musthofa, on the other hand, argued that ethics is closely related to philosophy. Philosophy is a means to understand and emulate the deeds of God as their best. According to al-Kindi, human beings can reach virtue by conducting good behaviors which can be implemented through hikmah (wisdom), an-najdah (courage), and iffah (purity).

According to Aristotle (cited in Suseno, 2003: 78), ethics is not influenced by various mystical beliefs. In his opinion ethics is a branch of science which talks about moral philosophy.

Similar to previous philosophers such as Socrates, Plato, and Aristotle, Shand (cited in Tjahyadi, 2004: 70) stated that the essence initiated in ethics is that the final destination of human beings is eudaimonia (happiness), because human will do not need anything else as long as they are happy. The concept of ethics in Aristotle's view also explains more on how humans achieve euzen

el Harakah Jurnal Budaya Islam Vol. 19 No.2 Tahun 2017 
(good life) as much as possible. Therefore, in Aristotle's opinion, humans will gain a good life if they can reach their final destination, namely happiness.

According to Aristotle (in Mu'thi, 1992: 52-53) sufficient knowledge is not enough for humans to gain the happiness, because they need to take proper actions which are actually the realization of typical human ability: ratio and reason. Therefore, the more humans act by involving ratio and reason the happier they will be.

Furthermore, Aristotle stated that the typical activities of ratio can be classified into two categories: theoria and praxis. Theoria here does not mean "theory" as a deep rational thinking about certain problem, but theoria here is contemplation. Theoria here means considering and contemplating the nature of reality deeply. According to Suseno (2003: 33), contemplation is a very highly human activity, even divine activity. Contemplation is philosopher's activity, while the meaning of philosopher itself is philo-sophia (a person who loves wisdom). Therefore, activities which make human happy are philosophical activity, thinking as well as contemplating eternal and divine matters.

Based on the aforementioned definitions about ethics, it can be concluded that ethics is a common moral behavior which determines good and bad, right and wrong in societal life. Ethic values in human life can be achieved through both intellectual virtue (ratio) and moral virtue.

\section{Research Method}

This research is basically library research because research objects, references, and documents are based on resources obtained from library and "penghayat" community. The main research object is the guidance used by PSHK in South Cilacap, Central Java.

Because of the stated problems, this research will not examine statistical data, use mathematical logic, or generalize research data. Therefore, this research can be categorized as qualitative research (Moehadjir, 1996: 9). According to Lincoln and Denzin (2009: 2) qualitative research is focusing on various methods which cover interpretive and naturalistic approaches in the study.

This research is specifically discussing the meanings contained in the guidance books used by PSHK and applying content analysis which is a strategy to catch the messages of a text (Endraswara, 2008: 161). The use of content analysis in this research is aimed to gain the results which lead the researcher to make a generalization. The meaning of generalization here is that the results of the research contain theoretical contribution (Moehadjir, 
1996: 77). Meanwhile, Holsti (1969: 601) assumed that content analysis is a random research technique to make a conclusion through identifying certain characteristics of messages systematically and objectively. Therefore, content analysis is researchers' attempt to understand and reveal extrinsic aspect of the literature such as moral, educational, philosophical, religious, and historical messages.

Research data were collected through documentation by tracing and seeking the guidance books of PSHK as the main resource for the group. In addition, the researchers also collected additional information from other books, magazines, articles, and other kinds of resources discussing about PSHK. In the research field, the guidance book of PSHK is called as primary data while other information from other kinds of written materials are called as secondary data (Hadi, 1983: 9)

In order to analyze the data, the researchers used semiotics, namely trying to find hidden meaning contained in the guidance book of PSHK. By using semiotics, the researchers were eager to know the signifier and signified in the book. Signifier can be classified into icons, indexes, and symbols (Pradopo et al., 2003: 68).

\section{Results and Discussion}

\section{Social Setting of Paguyuban Suci Hati Kasampurnan (PSHK)}

This "paguyuban" was founded by Nadam Wirjamhardja on July, 19, 1939 in Notog Banyumas. Nadam received ilham (spiritual inspiration) about kasampurnan (the perfection of life) from God. This teaching then was taught to the people in Banyumas, Cilacap, Purbalingga, dan Banjarnegara. As the time flies, the teaching spreads to Jakarta, Bogor, and outside Java. At that time, this "paguyuban" was not well-organized yet; this "paguyuban" has gradually become well-organized since 1971, just prior to the time of general election (Hartini, 2014).

There are many adherents of this "paguyuban" who are living in different districts. Here are the numbers of the adherents of PSHK in Cicacap.

Table 1: The number of people believing in the One Almighty God in Cilacap

\begin{tabular}{lllll}
\hline No & District & Male & Female & Total \\
\hline 1 & Kedungreja & 20 & 21 & 41 \\
\hline 2 & Kesugihan & 14 & 14 & 28 \\
\hline 3 & Adipala & 41 & 41 & 82 \\
\hline
\end{tabular}

el Harakah Jurnal Budaya Islam Vol. 19 No.2 Tahun 2017 


\begin{tabular}{lllll}
\hline 4 & Binangun & 29 & 32 & 61 \\
\hline 5 & Nusawungu & 39 & 40 & 79 \\
\hline 6 & Kroya & 10 & 7 & 17 \\
\hline 7 & Maos & 22 & 11 & 33 \\
\hline 8 & Jeruklegi & 8 & 6 & 14 \\
\hline 9 & Kawunganten & 65 & 57 & 122 \\
\hline 10 & Gandrungmangu & 110 & 99 & 209 \\
\hline 11 & Sidareja & 59 & 64 & 123 \\
\hline 12 & Karangpucung & 0 & 0 & 0 \\
\hline 13 & Cimangu & 6 & 2 & 8 \\
\hline 14 & Majenang & 9 & 5 & 14 \\
\hline 15 & Wanareja & 71 & 76 & 124 \\
\hline 16 & Dayeuhluhur & 3 & 1 & 4 \\
\hline 17 & Sampang & 5 & 3 & 8 \\
\hline 18 & Cipari & 66 & 58 & 124 \\
\hline 19 & Patimuan & 9 & 11 & 20 \\
\hline 20 & Bantarsari & 88 & 103 & 191 \\
\hline 21 & Cilacap Selatan & 12 & 4 & 16 \\
\hline 22 & Cilacap Tengah & 26 & 17 & 43 \\
\hline 23 & Cilacap Tengah & 6 & 10 & 16 \\
\hline 24 & Kampung Laut & 6 & 7 & 13 \\
\hline & Total & 724 & 689 & 1.413 \\
\hline
\end{tabular}

Source: Ministry of Religious Affairs Cilacap (2016, 33).

\section{The Sources of PSHK}

Actually, there are similarities among various "penghayat" groups in terms of guidance book. Most of them use Kitab Adam Makna as the main source of their teachings. So does PSHK. In addition to "Kitab Adam Makna", this book has also various names such as: Kitab Wujud, Kitab Jagat Gumelar, Kitab Teles, and Kitab Turki or Turni.

Here are the explanations why the book is called as such the names:

1. Kitab Adam Makna. Adam means existence, while Makna means meaning;

2. Kitab Wujud means all the existences in this world are a created by God and they are essentially God's book which contain meaning;

3. Kitab Jagat Gumelar means that everything in this world has meaning;

4. Kitab Teles means that all God's creatures, including humans, are the evidence of God's existence; 
5. Kitab Turki/Turni is an abbreviation of "Pituture si Kaki/Piturure si Nini". It means that the book contains valuable advices, proverbs, and utterances from ancestors (HP and Sariwardhani, nd: 20)

Those five sources are sastra tanpa tulis. It literally means unwritten literatures, or it can also be called as oral tradition because at that time people had not come into written civilization; they had not recognized Javanese letters, cuneiform, Chinese letters, or other kinds of alphabets. Therefore, people used various symbols neatly wrapped in ritual offerings, ceremonies, fairytales, folklores, songs, dances, art performance, and so on (interview with Muslam, 29 September 2016).

\section{The Teachings of PSHK}

\section{Human Concept}

According to AD/ART (statutes/ articles of constitution) of PSHK, there are five main teachings of this group. They are conducting good behaviors, committing no ma lima but performing ma tiga, becoming strong and tough human, royal to the government, and becoming human beings completely.

The explanation about ma lima are as follows. Ma lima means five ma from which Javanese people in general, or the adherents of the PSHK in particular, have to stay away. The first ma is madat. It means "opiate". Madat is getting addicted to addictive things such as marijuana, crystal meth, and so forth. The term madat here means that the adherents of PSHK are not allowed to consume addictive things in order to achieve high position by behaving well. The second ma is madon which literally means "woman". The term madon here means that the adherents of PSHK are forbidden to have a special relationship (in love) with other women (could be friends, working colleagues, and so on) except their wives because having such relationship is illegal. In a more clear statement, it is strongly forbidden for PSHK adherents to be close to prostitution. In other words, they are not allowed to commit free sex. The third ma is maling which literally means "to steal". By categorizing maling as one of the term ma in the concept of ma lima, it means that the adherents of PSHK are not allowed to take others' property without permission. The fourth $m a$ is main which literally means "to play". However, the term main here does not mean that the adherents of PSHK are not permitted to play games. On the contrary, the term main here means that they are forbidden to do gambling in its various forms. The last ma is minum which means "to drink". It does not 
mean that the adherents of PSHK are not allowed to drink water, milk, juice and so forth, but it is forbidden for them to get drunk.

The concept of ma lima is considered as ethic theory which according to Syukur is synonymous with moral ethic. Musthofa also said that ethics always relates to philosophy, even al-Kindi stated that in order to gain virtue, humans have to uphold morality. Therefore, morality becomes the main teaching in PSHK in order to prepare its adherents and young people to face modern era which are full of challenges, particularly to face negative behaviors and cultures which are not appropriate with the norms.

Another teaching of the PSHK is the concept of ma tiga (it literally means three $\mathrm{ma}$ ). In contrary with ma lima which have to be avoided by the adherents, the concept of ma tiga is three ma which has to be conducted by the adherents. By performing ma tiga, humans can strongly combat ma lima. Similar to ma lima, ma tiga is the concept relates to $m a$, but different in numbers. If ma lima consists of five ma, ma tiga consists of three ma which are originally Javanese words. They are madhep, mantep, and mituhu. The first ma is madhep, which literally means "to face towards a certain direction". However, the term madhep here is meant to worship the One Almighty God and obey Him. The second and the third ma are mantep and mituhu. Mantep literally means "steady, firm, being convinced", while mituhu means "to obey, loyal". These two concepts teach the adherents of the PSHK to trust their parents and obey them. Therefore, the adherents of PSHK have to obey not only the One Almighty God but also their parents. In addition, they also have to be honest, tell the truth, not hurt others, and be humble people as well as have other positive personalities.

The two concepts of ma lima and ma tiga have been set in the statutes of PSHK. In the statutes, it is clearly stated that the requirement to become the adherents of the PSHK are as follow: 1) Indonesians, male or female, promise to obey the rules of the PSHK; 2) follow the group consciously, neither influenced by others nor under the threat; 3 ) not a member of political party; 4) obey the advice and instructions of the PSHK elders; and 5) not a criminal which is shown by a certificate issued by the police (intervew with Rahardjo, 29 November 2016).

Based on the teachings and requirements to become an adherent of PSHK, it can be said that the group actually demands each adherent to be good person, to be a perfect human, to be a strong person, and to be a major warrior. Human in the PSHK's concept is depicted as a warrior. Warrior is 
a strong and tough figure who will never give up in dealing with his duties, no matter how hard they are. In sequence, PSHK examines the adherents not only by employing spiritual exercises but also by using the physical ones. In terms of physical exercises, they are trained a kind of self-defense which is called as gerak rasa Antasena (gerantas). Antasena is a strong figure who is very tough in facing many problems, challenges, and dangers for the sake of truth and justice. He is also known as a figure who always keeps his words.

Moreover, PSHK also teaches the adherents to obey the regulation issued by Indonesian government and give their high loyalty to Pancasila and UUD 1945 as the basic principles of Indonesia. They also teach the adherents to willingly sacrifice for the nation and the state. They are all conducted for creating a good generation who have good characters and perform good actions and behaviors.

According to Basuki $(2015: 22)$ humanity is part of the human attributes in its function as a living being created by God in the process of living in the world. Humanity consists of three main elements: the mind or thought, intention, and feeling. Thus it can be explained that the concept of human according to the adherents of the PSHK is the most respected creature, because he was given the ability to determine their will and choices.

The doctrine of ma tiga in the concept of ethics or moral philosophy as described above teach people, especially the adherents of PSHK, to always madep (testify and be convinced) to the One Almighty God as the source of life who creates humans. According to Rahardjo (interview, 28 November 2016) humans are basically there as the proof of the existence of God, then he should nyembah (worship, prayer) Him to achieve kamulyan (happiness). Sembahyang which is the activity of nyembah can be conducted in sentong (a certain place for the adherents to perform prayer/sembahyang), pasemon, paseban, and other sacred places. In addition, they also have to mantep (obey) their parents. These teachings are taught to all humans without any exception including the adherents of PSHK.

In Islamic ethics, the teaching of devout and being good towards parents is clearly stated in the Holy Qur'an at least in two verses of the Surah al-Isra'. The verses say as follow:

"And your Lord has commanded that you worship none but Him, and that you be good to your parents. If either of them or both of them reach old age with you, do not say to them a word of disrespected, nor scold them, but say to them kind words. And lower to them the wing of humility, out of 
mercy, and say, "My Lord, have mercy on them, as they raised me when I was a child. (QS. Al-Isra, 23-24) (http://www.clearquran.com/017.html, accessed on January, 30, 2017)

In the teachings of PSHK, the obligation to be devout to the parents is a requirement to gain good characters, because they are the people who gave birth to their children, nurture them, feed them, and provide them with education. According to Mu'thi, the doctrine of mantep taught in PSHK is actually relevant to the theory of ethics proposed by Aristotle, namely achieving happiness. People can be happy if they perform good behaviors and characters, one of them is obeying their parents.

The other concept of ma tiga is mituhu which also means to obey, to be obedient. Different from the second concept in which the obedient is addressed to the parents, the obedient in the concept of mituhu is addressed to teachers. Whoever obeying his/her teachers will get the perfect life. By implementing mituhu to the teachers someone has conducted one form of good characters as a branch of ethics. In the KBBI ethics is described as a brand of science which deals with good and bad, right and wrong, and moral obligation. In short, ethics is a set of values in human life. Therefore, the doctrine of mantep is a set of moral values which is learnt by the adherents of PSHK then internalized and implemented in their daily lives.

\section{God in Concept}

The concept of God is called as purwo madiyo wasono. It becomes the core teaching of PSHK. The meaning of this Javanese puwo madiyo wasono is that the nature of everything does not exist, and then they exist and will no longer exist. The explanation of the concept of God can be found in the teachings of the group; everything is a symbol that actually would be understandable for the seeker who has received wejangan-wejangan (suggestions and advices) directly from the elders, teachers, or the wiku of PSHK.

The best symbol in the concept of God is warongko manjing curigo that can also be understood as lenggahing kawula gusti. By understanding this symbol, the adherents will know the position between gusti (Lord) and kawula (servants) well. People who have been able to accept and understand what the meaning of purwo madyo wasono will understand that life consists of four main aspects: 1) dzat, 2) shifat, 3) asma, and 4) apengal. These four elements exist at the same time as humans are born. Before humans are born the four elements 
did not exist yet. When the humans do not exist anymore, these four elements will disappear as well. They must be also returned to their respective origins.

These four elements will also result four aspects. They are 1) lakune rogo (physical exercises), 2) lakune budi (reasonal exercises), 3) lakune ati (spiritual exercises), and 4) lakune rasa. Among the four, it is lakune raga that always harmonizes others in order to stay healthy. This is the so-called memayu hayuning pribadi or always being introspective.

According to Basuki (2016: 55), the fundamental basis for "penghayat", such as the adherents of PSHK, is spiritual exercises which are addressed to pure their life and to increase their spiritual level by implementing the following principles. The first is holding strong determination. Determination is a self-process in certain "laku" which is together with the reason guide a person to the right way. The second is belief. Believing in God purely which marks humans' life will lead them to "sangkan paraning dumadi". The third is total submission. Humans have to surrender and submit to God totally (either physical, mental, or spiritual) after receiving the touch of living $d z a t$ and understanding it.

Laku raga (physical exercises) in the teaching of the group means that the adherents will always show positive attitudes in their life, such as being confidence, polite, forgiving, discipline, responsible, and care to others (Hartini, 2014), while laku budi (rational exercise) means that all people in general, and the adherents of PSHK in particular, have to perform good characters and behaviors. This teaching is also called as satria (knight). Good knight is a person who is well-mannered and well-behaved, brave enough, heroic, helpful, and friendly. In a clearer explanation, a good knight is a perfect and complete human being, both physically and spiritually. Satria is formed from three syllables: sa, tri, and ya. Sa means sawiji, manunggal (unity), tri means tiga (three), and ya means lokaya, jagad (worlds). So, the person who is considered as satria (knight) is a person who is able to unite three worlds, guruloka, hendraloka, and janaloka (Hartini, 2014: page).

Guruloka (head) is a place of thought and mind. In Javanese daily language, the guruloka is also called as kawruh (knowledge), while hendraloka is a place of passion which is located in the chest. It means that hendraloka is a part of the three worlds which has to manage humans' desires. The third, janaloka, is a world which relates to genital and reproductive organs. The responsibility of this world is producing new generation who is better, more productive, and

el Harakah Jurnal Budaya Islam Vol. 19 No.2 Tahun 2017 
more qualified than previous generations. This is the so-called as rahayuning tedhak turun in Kejawen (Hartini, 2014).

In conclusion, laku raga and laku budi is a group of people or the adherents of certain "penghayat" groups who is able to harmonize body and soul in order to stay healthy. In addition, they have to be patient and berbudi bawa laksana, which means being able to differentiate between good and bad and understand the difference between God's kodrat and wiradat.

The other two teachings of PSHK, laku ati (spiritual exercises) and laku rasa (feeling exercises), mean that a person in general or the adherents of PSHK in particular have to submit themselves to God totally and obey Him. They have to become pious people and also understand the position between the worshipper and the worshipped; understand the difference between kawula (servant) and gusti (lord) (rangka manjing curiga).

\section{Spiritual Symbols of Kejawen Tradition}

The teachings of PSHK are really associated with ritual symbols which are regarded as a way of life. Spiritual symbols in Java or Javanese tradition are called as sastra tanpa tulis (spoken literatures). Sastra means "a lesson" or "knowledge", tanpa means "no" or "without" and tulis means "writing". Thus, sastra tanpa tulis is doctrine or knowledge which is not written because it has not been created yet. Sastra tanpa tulis takes the form of emblems, symbols or ciphers, rituals, ordinances, ceremonies, traditions, songs, oral stories, and so on. (HP and Sariwardhani, nd: 20)

Sastra tanpa tulis is also known as the Kitab Adam Makna. Kitab Adam Makna comes from "Kitab" means the book, Adam means exist, and Makna means meaning. Thus it can be argued that Kitab Adam Makna is the book that exists, unfolded in the universe, unwritten, and it becomes a symbol of the Javanese communities' mores. The following are the examples of spiritual symbols for the believer in particular and Javanese society in general. They are the terms rangka manjing curigo (seith inside dagger), tumpeng (rice served in a cone shape), ambeng (fragrant rice dish consists of white rice prepared with chicken curry or chicken cooked in soy sauce, vegetables, fried noodles, some salted fish, fried coconut flesh, and so on), jajan pasar (various traditional snacks bought from market), kembang (flowers), wedang/unjukan (drinking water), bubur/jenang (porridge), janur kuning (young coconut leaf), kemenyan (incense), cemara (cypress), pala gumantung (kinds of fruits on the trees, not buried under the earth), degan (young coconut), diyan dlepak (traditional light), the head of 
buffalo, cikal (young coconut tree), pisang raja setangkep (two bunches of raja banana), pisang Ambon (Ambonese banana), suruh ayu temu rose (certain betel with specific criteria, usually betel whose leafs segments meet each other), sego golong pitu (seven rolled rice which is served in the cylinder), ingkung (chicken served in its complete parts, without being cut), and so on (HP and Sariwardhani, nd: 20-28).

Such symbols, either in the form of language expression or ritual symbol, actually have a deep philosophical meaning for Javanese community. For instance, tumpeng, it can be divided into three parts, the base is called as purwa, the middle is called as madya, and the top is called as wasana. In the puppet show, tumpeng which is symbolized with gunungan (which literally means mountain) is also performed three times, in the beginning, in the middle, and at the end of the performance. In Kejawen, the three parts of tumpeng can be considered as the symbols of life periods: namely the beginning, the process or life itself, and the end. In addition, tumpeng is also a symbol of divinity in which it is only God who has absolute right to create the world, manage and rule it, and destroy it as well (Judgment day) (HP and Sariwardhani, nd: 20).

Concerning its level has four levels, namely heneng, hening, huni, and hani. The first level, heneng, which is symbolized by the base part of tumpeng consisting of various dishes, means that ethnic, racial, customs, culture, ordinances and ceremonies, and religious rituals are different. This basic level in kejawen tradition is referred to syariat (law) level. The second level is hening (silence) which is symbolized by rice. The rice is viewed from all directions. This second level includes someone or group of people who have reached the degree of tarekat. Then the third level is huni (occupied) which is corresponding to the second level. If tumpeng is seen from different angles, it is the same, but the shape of rice will become smaller (narrower). The third level is referred to hakekat. The fourth level is hani which is symbolized by the peak of tumpeng which leads to the highest point. The top of the tumpeng is also called as puncet. It means being closer to God the Almighty as the culmination of the masters of universe. In Islam, hani is also known as makrifat.

Tumpeng is a symbol manembah (to worship) to God. In semiotic theory tumpeng is a symbol and the meaning is a signifier for "penghayat". Levels in tumpeng actually describe the spiritual journey of Javanese people in worshiping God. The first level can be described as common people who worship God limited to the meaning of the shari'a. An adherent of "penghayat" then can reach the top after climbing the other next levels: tarekat, hakekat, and makrifat.

el Harakah Jurnal Budaya Islam Vol. 19 No.2 Tahun 2017 
According to Kejawen teaching people who can reach the top position is considered as being on the level of manunggaling kawula gusti.

Actually, the sources of Kejawen teachings cannot be separated from the philosophical meaning of Javanese life itself. Javanese community, in the practice of social life, economy, ritual, and culture always deal with philosophical values which are implemented in daily lives. Javanese philosophy as described by Wibawa (2013: 328) in Serat Centini are as follows: First, the Javanese values in Serat Centini reflects the content of Javanese culture and philosophy as well as the state of the Javanese community in the time Serat Centini was written. Javanese philosophy in Serat Centini is reflected in ngudi kasampurnan (seeking the perfect life) and the philosophy of sangkan paraning dumadi (the philosophy about the origins and the goals of existing lives).

The second, philosophy of Serat Centini is reflected in ontological, epistemological, and axiological levels. The sources and the teachings of PSHK are actually similar to Serat Centini in terms of ontological, epistemological, and axiological. In the review of the ontology aspects, the teaching of PSHK is trying to find the hakikat (essence) of thing that is God. According to Bergson (cited in Praja, 2010: 178) the form of the highest belief is mysticism. Thus, the highest achievement in PSHK is achieving spiritual mysticism by performing various mystical rituals in order to gain kasampurnan sejati (the real perfection). By performing laku rasa, a seeker will meet God which is also known as manunggaling kawula gusti. According to Achmad (2014: 153), a person who wishes to reach the level of manunggaling kawula gusti has to unite himself to the God. In a wider context, the person has to conduct all His orders and stay away from His prohibitions. If he/she can do it, the person will be happy both in the world and hereafter.

The intimacy between human and God is a metaphor between kawula (servants) and gusti (lord) (Endraswara, 2015: 229). In the context of Javanese culture, the term manunggalaing kawula gusti is usually used in two contexts: social cultural and religious spiritual. For Javanese people the term is actually infinite personal experiences which are difficult to describe through words. In addition, the experiences also relate to mental (feeling) of a person who reached the ascetic with God.

Javanese people can achieve the perfection of life if they have knowledge (epistemology) and actualize the knowledge into good actions. The good actions are addressed not only to human beings but also to the universe which are 
actually the parts of unwritten book. This unwritten book does in fact contain meaningful symbols and philosophical meaning.

The adherents of PSHK maintain natural ecosystems by preserving the universe which is known as memayu hayuning bawana in Javanese language (HP and Sariwardhani, nd: 34). Preserving the universe is actualized in the forms of ritual and ceremonies, such as rawat bumi/selamatan bumi (a ritual of slametan which aims to have earth safety), ruwat banyu (certain ritual to have water safety), ruwat kewan/barit rajakaya (a certain ritual to have animals safety), bersih desa (certain ritual to get a clean village), ruwat langit (certain ritual to have sky safety), and so on.

\section{Conclusion}

Based on the previous explanations about the sources and the teachings of PSHK, it can be summed up as follows: 1) the source of the teachings used by Paguyuban Suci Hati Kasampurnan (PSHK) is not only from written book, but also from Kitab Adam Makna in the form of symbols found in the universe. 2) The core teaching of PSHK is performing good actions in life which can be implemented through laku raga, laku budi, laku ati, and laku rasa. By performing those four laku, it means that the adherents of the PSHK have practiced ethical and moral values and implemented those values in their daily lives.

\section{References}

Achmad, Sri Wintala. 2014. Ensiklopedia Kearifan Jawa: Menggali Mutiara Kearifan Jawa Berdasar Karya Agung Para Pujangga. Yogyakarta: Araska.

Basuki, Hertoto. 2015. Mengenal Kepercayaan terhadap Tuhan Yang Maha Esa Laku Hidup dalam Managemen Manunggaling Kawulo Gusti. Semarang: Mimbar.

Bertens, K. 2007. Etika. Jakarta: PT. Gramedia Pustaka Utama.

Endraswara, Suwardi. 2008. Metodologi Penelitian Epistimologi, Model, Teori, dan Aplikasi, Yogyakarta: Med Press.

Endraswara, Suwardi. 2015. Agama Jawa Ajaran, Amalan, dan Asal Usul Kejawen. Yogyakarta: Narasi - Lembu Jawa.

Fauziyah, Siti. 2014. Spiritualitas Penghayat Ajaran Kapribaden di Desa Kalinongko Kecamatan Loano Kabupaten Purworejo. Undergraduate thesis, The 
Faculty of Ushuluddin and Islamic Thought Sunan Kalijaga State Islamic University.

Hadi, Sutrisno. 1983. Metodologi Research. Yogyakarta: Yayasan Penerbitan Fakultas Psikologi Universitas Gadjah Mada.

Hartini, Sri. 2014. Majelis Luhur Kepercayaan terhadap Tuhan Yang Maha Wadah Nasional Tunggal Organisasi/Kelompok Penghayat Kepercayaan terhadap Tuhan Yang Maha Esa. Jakarta: Dewan Pusat MLKI.

Holsti, Ole R., 1969. Content Analysis for the Social Sciences and Humanities. Reading: Addison-Wesley.

HP, Muslam and Sariwardhani. nd. Adat Istiadat Budaya Spiritual Komunitas Suku Jawa (Kejawen). Cilacap: Kelompok Studi Jawanology.

Lincoln, Yvonna S and Norman K. Denzin. 2009. Handbook of Qualitative Research. Terjemahan oleh Dariyanto, dkk. Yogyakarta: Pustaka Pelajar.

Magnis-Suseno SJ, Franz. 2003. Etika Jawa Sebuah Analisa Falsafi tentang Kebijaksanaan Hidup Jawa. Jakarta: PT. Gramedia Pustaka Utama.

Moehadjir, Noeng. 1996. Metodologi Penelitian Kualitatif. Yogyakarta: Rake Sarasin.

Mu'thi, Faruq Abd. 1992. Aristu: Ustadz Falasifat al-Yunan. Beirut: Dar alKutub Ilmiyah.

Pradopo, Rachmat Djoko, et al. 2003. Metodologi Penelitian Sastra. Yogyakarta: Hanindita Graha Widya.

Praja, Juhaya S. 2010. Aliran-Aliran Filsafat dan Etika. Jakarta: Kencana.

Qur'an in English. http://www.clearquran.com/017.html, (accessed on January, 30, 2017)

Rofiudin. 26 Juli 2016. Tolak Ikut Pelajaran Agama, Siswa SMK ini Tidak Naik Kelas. Suara Merdeka Semarang: halaman: nomor kolom.

Rosidi, Achmad. 2011. Perkembangan Paham Keagamaan Lokal di Indonesia. Jakarta: Kementerian Agama RI Badan Litbang dan Diklat.

Syukur, Amin. 2010. Studi Akhlak. Semarang: Walisongo Press 
Tjahjadi, Simon Petrus L. 2004. Petualangan Intelektual Konfrontasi dengan para Filsuf dari Zaman Yunani hingga Zaman Modern. Yogyakarta : Kanisius.

Wibawa, Sutrisna. 2013. Nilai Filosofi Jawa dalam Serat Centini. Jurnal Litera Vol. 12, Nomor 2.

el Harakah Jurnal Budaya Islam Vol. 19 No.2 Tahun 2017 
